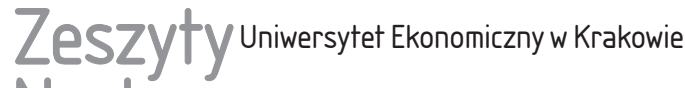 Naukowe
}

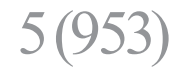

ISSN 1898-6447

Zesz. Nauk. UEK, 2016; 5 (953): 89-106

DOI: 10.15678/ZNUEK.2016.0953.0506

\author{
Sylwia Guzdek
}

\section{Współpraca gospodarcza jako czynnik rozwoju współczesnego przedsiębiorstwa*}

\section{Streszczenie}

Współpraca gospodarcza jest pojęciem wielopłaszczyznowym, trudnym do sklasyfikowania. Liczne badania naukowe potwierdzają złożoność form relacji międzyorganizacyjnych. W artykule podjęto próbę ogólnego zarysowania korzyści i zagrożeń dotyczących współpracy gospodarczej. Celem pracy było dokonanie na podstawie analizy literatury przedmiotu omówienia istoty współpracy gospodarczej, jej typów oraz znaczenia dla uczestniczących w niej podmiotów. Postawiono hipotezę badawczą, że współpraca gospodarcza stanowi jedno z głównych uwarunkowań rozwoju współczesnego przedsiębiorstwa.

Słowa kluczowe: współpraca gospodarcza, kooperacja, koncentracja, przedsiębiorstwo, korporacje transnarodowe.

Klasyfikacja JEL: M2, P13.

\section{Wprowadzenie}

We współczesnej gospodarce światowej coraz bardziej rozpowszechnia się przekonanie o potrzebie zastąpienia prowadzenia bezwzględnej konkurencji między firmami zawieraniem porozumień i podejmowaniem wzajemnej współ-

Sylwia Guzdek, Uniwersytet Ekonomiczny w Krakowie, Katedra Mikroekonomii, 31-510 Kraków, ul. Rakowicka 27, e-mail: guzdeks@uek.krakow.pl

* Artykuł powstał w ramach tematu badawczego sfinansowanego ze środków przyznanych Wydziałowi Ekonomii i Stosunków Międzynarodowych Uniwersytetu Ekonomicznego w Krakowie w ramach dotacji na utrzymanie potencjału badawczego. 
pracy, wynikającej z konieczności realizacji wspólnych projektów, ale także ze wzrastającej popularności outsourcingu i liczby przedsiębiorstw działających w ramach powiązań sieciowych.

Celem badawczym niniejszego opracowania jest próba analizy współpracy gospodarczej między przedsiębiorstwami. Ponieważ problematyka współpracy gospodarczej jest wielopłaszczyznowa, dokonano selektywnego wyboru jej poszczególnych aspektów uznanych za najważniejsze: istoty współpracy gospodarczej, jej typów oraz znaczenia dla uczestniczących w niej podmiotów. Postawiono hipotezę badawczą, że współpraca gospodarcza stanowi jedno z głównych uwarunkowań rozwoju współczesnego przedsiębiorstwa.

\section{Istota wspólpracy gospodarczej przedsiębiorstw}

Współczesna gospodarka jest siecią relacji korzystnych lub niekorzystnych, dobrowolnych lub wymuszonych między przedsiębiorstwami powiązanymi $\mathrm{z}$ innymi podmiotami otoczenia, w którym funkcjonują. Współdziałanie gospodarcze, partnerstwo, koordynacja, kooperacja, alianse, koopetycja i kooperencja ${ }^{1}$ to niektóre z pojęć dotyczących zjawiska współpracy. W literaturze przedmiotu używa się także pojęcia orientacji na współpracę². Najczęściej jednak definiowane jest zjawisko współpracy z naciskiem na korzyści takiego współdziałania [Romanowska i Trocki 2002; Urbaniak 2000; Przedsiębiorstwo kooperujace 2002; Cygler 2009; Romanowska 1997; Strzyżewska 2011, s. 27-30].

Współpraca analizowana jest głównie na poziomie firmy jako całości, a także jej działów oraz grup lub poszczególnych pracowników. To relacja dwóch podmiotów oparta na współdziałaniu, które może być nastawione na wspólne wytwarzanie produktów, wymianę posiadanych zasobów własnych lub pozyskiwanie nowych, jak również wykorzystanie zasobów już dostępnych, np. w ramach izby gospodarczej, w celu uzyskania lepszych warunków działania [Jagoda 2001, s. 41-46].

1 Kooperencja to układ jednoczesnych, współzależnych relacji konkurencji i kooperacji między konkurentami zachowującymi swoją odrębność organizacyjną [Cygler 2009, s. 19].

2 ,Współpraca może być podejmowana w warunkach pozytywnego stosunku do niej menedżera lub z przymusu, np. ekonomicznego. Stąd pojęcie orientacji na współpracę. W literaturze można znaleźć stanowisko, zgodnie z którym współpraca jest utożsamiana z chęcią do organizowania działalności wspólnie z inną organizacją. Natomiast skłonność do współpracy oznacza postawę określonej osoby, np. kierowników firm, przedsiębiorców wobec współpracy z innymi przedsiębiorstwami. Postawa ta ma trzy wymiary: racjonalny, emocjonalny i behawioralny, czyli co dane osoby myślą, jakie są ich odczucia i działania w związku ze współpracą" [Strzyżewska 2011, s. 32]. 
Kooperacja jest pojęciem często używanym zamiennie ze współpracą, co wynika m.in. ze znacznej liczby cech wspólnych tych zjawisk, istotnych w relacjach międzyorganizacyjnych. Według M. Strzyżewskiej, kooperacja odnosi się jednak wyłącznie do organizacji pracy i samego procesu produkcji jakiegoś produktu lub realizacji określonego procesu produkcyjnego. Tym samym kooperacja to nie tyle wspólna praca, ile sposób realizacji określonego zadania produkcyjnego przez jego rozczłonkowanie [Strzyżewska 2011, s. 27-32].

Należy przychylić się do tego stanowiska, bowiem w klasycznym ujęciu kooperację definiowano w szerokim i wąskim znaczeniu. Przez kooperację w szerokim znaczeniu rozumiano współpracę przy wytwarzaniu wyrobów, zaopatrzeniu materiałowo-technicznym i świadczeniu usług. Kooperacja w znaczeniu wąskim ogranicza związki kooperacyjne jedynie do powiązań produkcyjnych przy wytwarzaniu wyrobów finalnych. Oznacza zatem bezpośrednią współpracę wyspecjalizowanych przedsiębiorstw i zakładów, między którymi występowały przepływy elementów kooperacyjnych, i świadczenie usług wykonywanych na specjalne zamówienie odbiorcy w ramach umowy kooperacyjnej, z przeznaczeniem do określonego wyrobu gotowego [Famielec 1992, s. 11-12].

Powszechnie stosowanym synonimem współpracy jest partnerstwo [Partnerstwo przedsiębiorstw... 2009]. M. Strzyżewska definiuje partnerstwo jako specyficzną formę współpracy, a za jej najistotniejszy element uznaje jakość relacji, w której dane działanie gospodarcze jest realizowane. Partnerstwo odwołuje się do wzajemnego zaufania, pomocy i sprawiedliwości. Nie każda współpraca opiera się na zasadzie partnerstwa. Partnerstwo zatem oznacza relacje jedynie równorzędnie traktujących się podmiotów. Można wyróżnić partnerstwo publiczno-prywatne czy partnerstwo w kanałach dystrybucji.

Pojęcie współpracy ewoluuje, rozszerza swój zakres, wzbogacając się o nowe formy. Obejmuje już nie tylko proces produkcji, ale i wymiany. Stopniowo poszerza się charakter relacji między przedsiębiorstwami oraz zbiór podmiotów w nich zaangażowanych: od dostawców i odbiorców, przez producentów wyrobów komplementarnych, do konkurentów. Ze względu na złożoność omawianego zagadnienia trudno znaleźć jedną dyscyplinę naukową zdolną całościowo objąć problematykę współpracy gospodarczej. Wymaga ona podejścia interdyscyplinarnego stosowanego przykładowo w socjoekonomii. Uwzględniając tę perspektywę badawczą, J. Światowiec-Szczepańska dokonała typologizacji teorii wyjaśniających istotę współpracy przedsiębiorstw (tabela 1).

Mnogość teorii wyjaśniających istotę współpracy gospodarczej pozwala wysunąć wniosek, że jest to pojęcie wieloaspektowe. Zakres jego można dodatkowo poszerzyć o koncepcję gron M.E. Portera [Przedsiębiorstwo partnerskie 2002, s. 16], paradygmat KKK [Sulejewicz 1997, s. 25, 64-68] czy kapitalizm aliansowy [Dunning 1995, 1997]. Przywołane teorie również analizują 


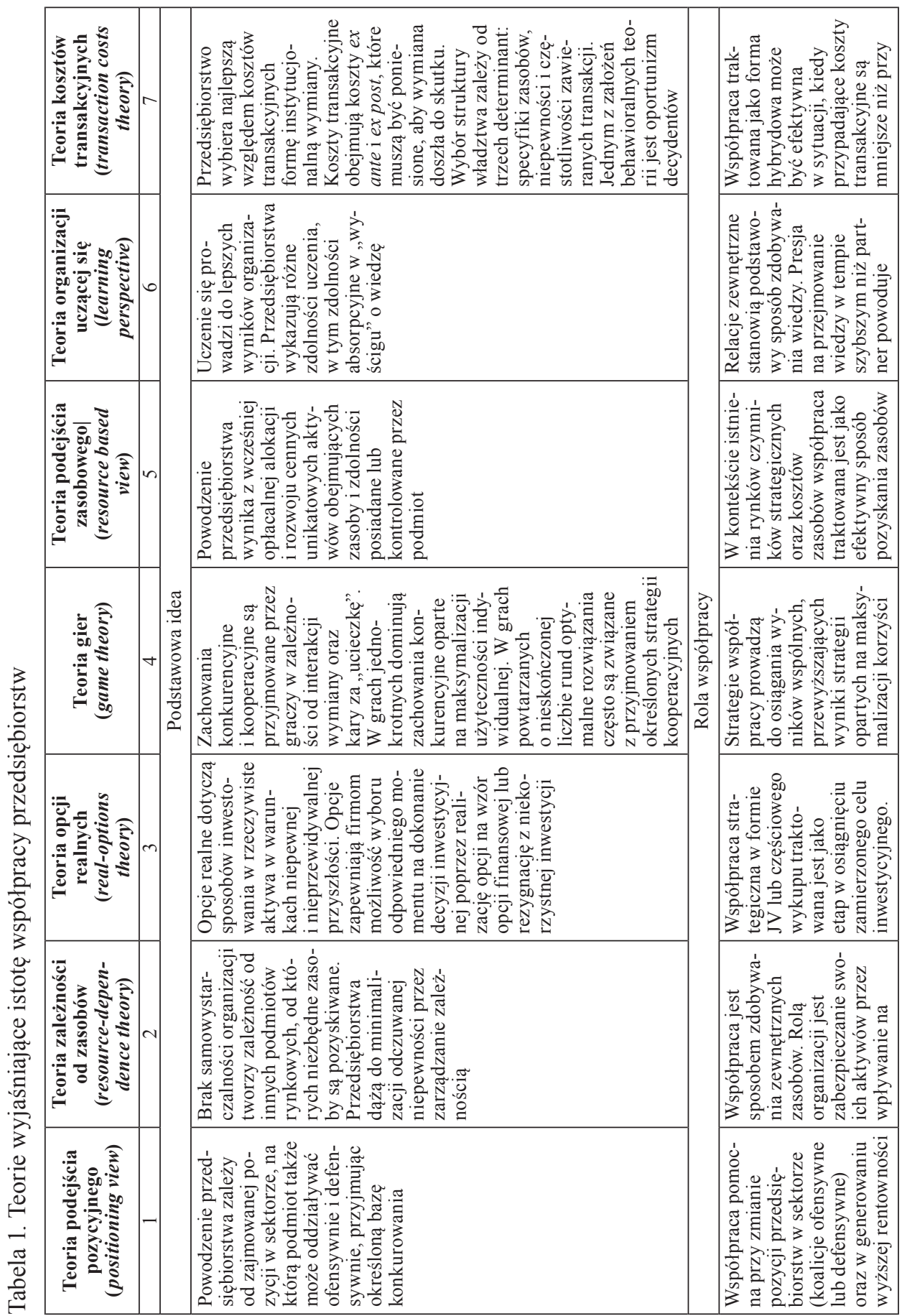




\begin{tabular}{|c|c|c|}
\hline 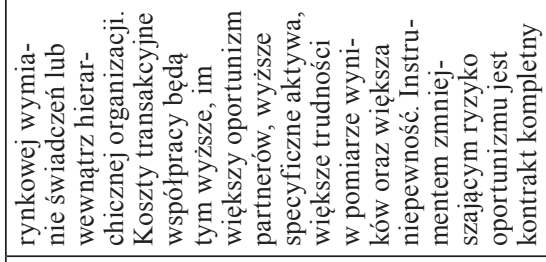 & & 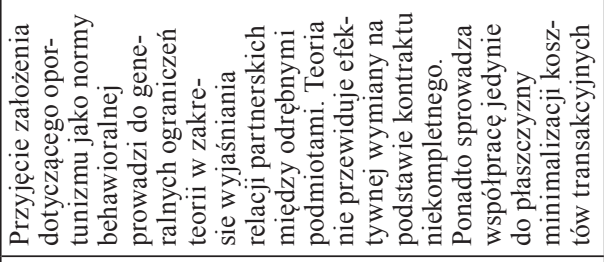 \\
\hline 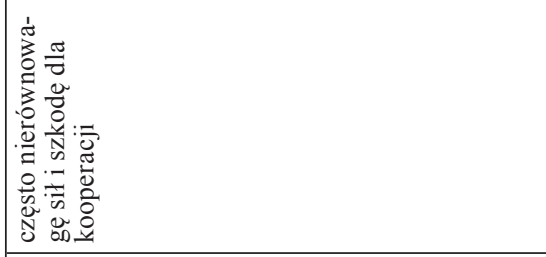 & & 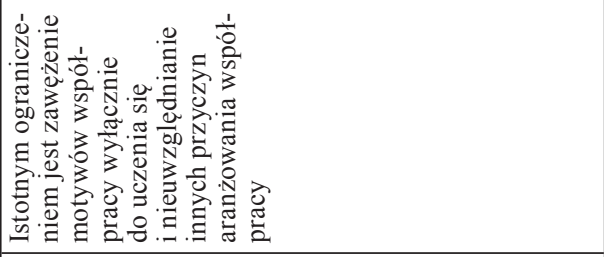 \\
\hline 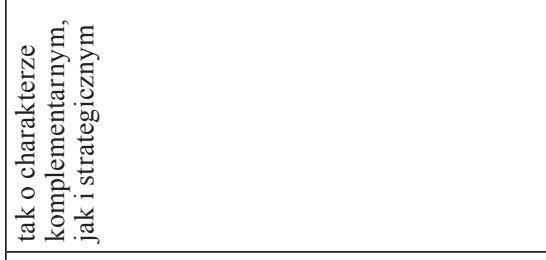 & $\begin{array}{l}0 \\
0 \\
0 \\
3\end{array}$ & 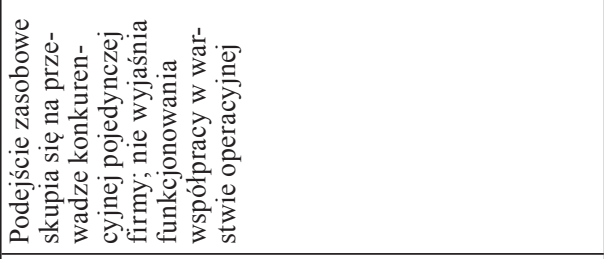 \\
\hline 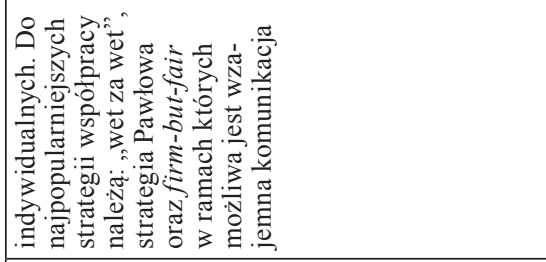 & 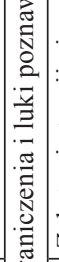 & 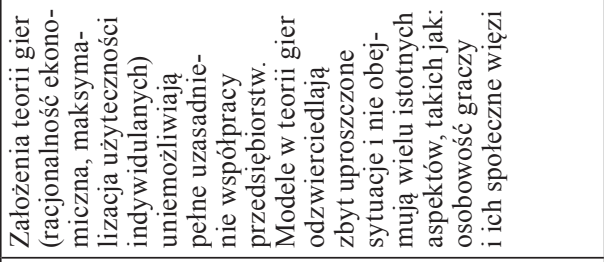 \\
\hline 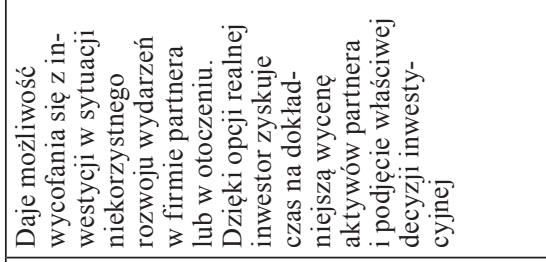 & 0 & 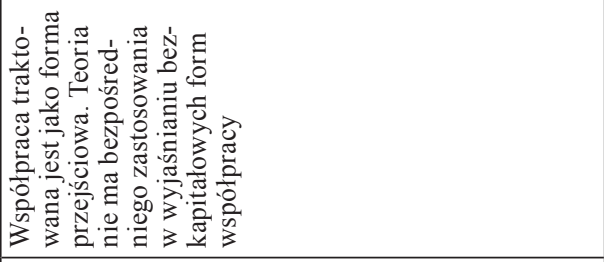 \\
\hline 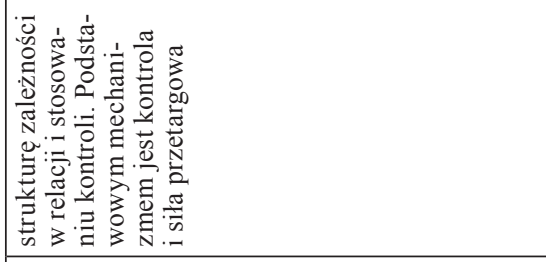 & & 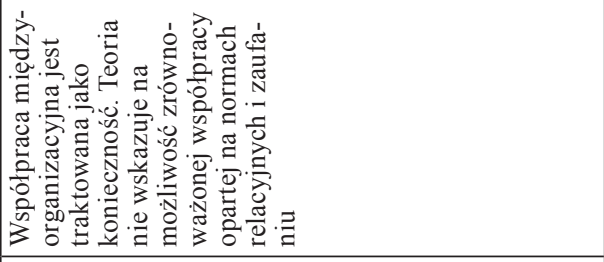 \\
\hline 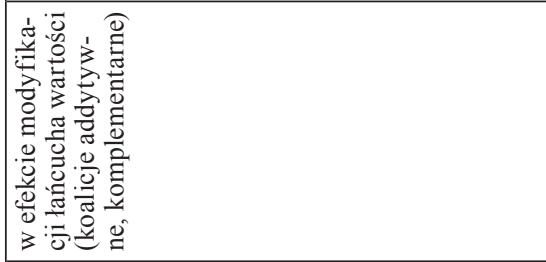 & & 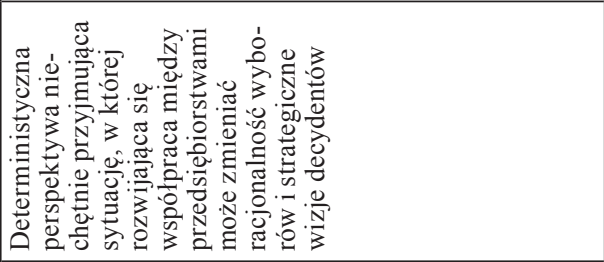 \\
\hline
\end{tabular}




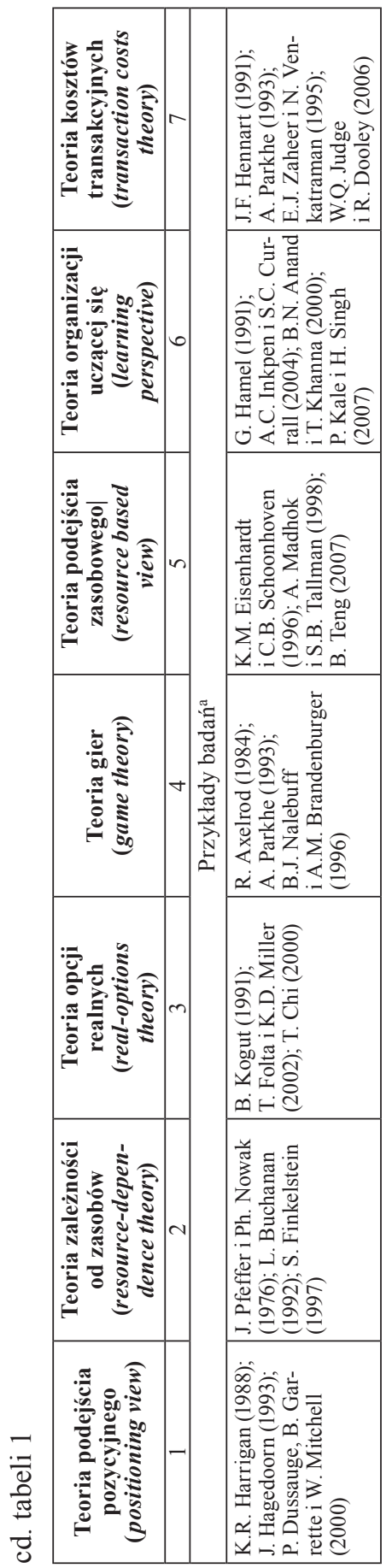

\begin{tabular}{|c|c|c|}
\hline 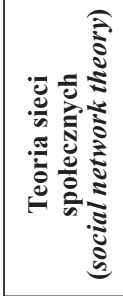 & $\cong$ & 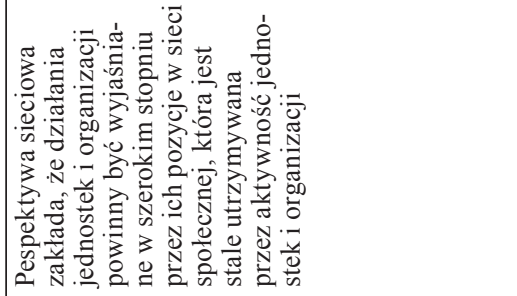 \\
\hline 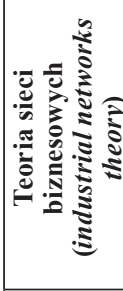 & & 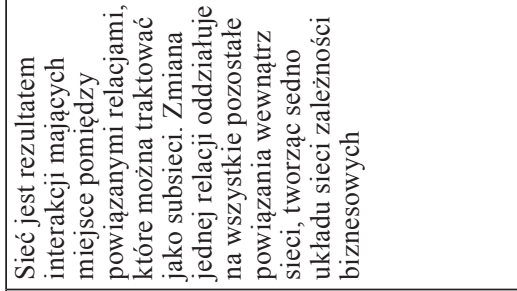 \\
\hline 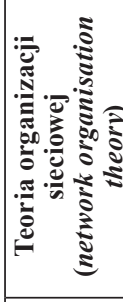 & 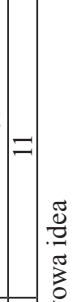 & 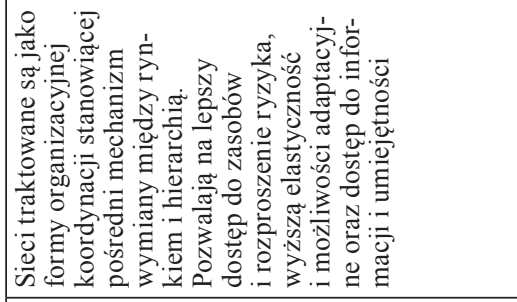 \\
\hline 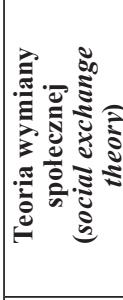 & 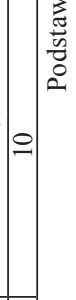 & 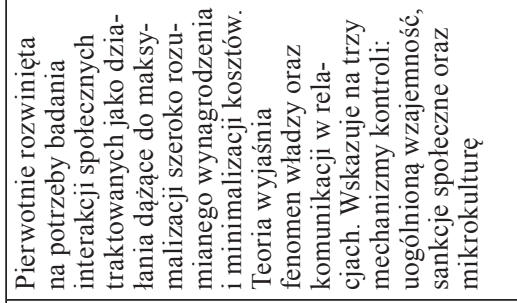 \\
\hline 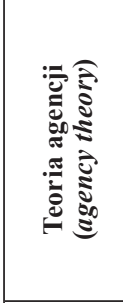 & $a$ & 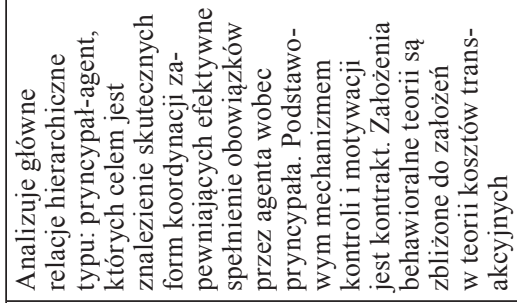 \\
\hline 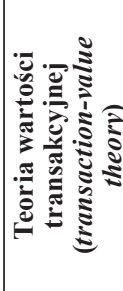 & & 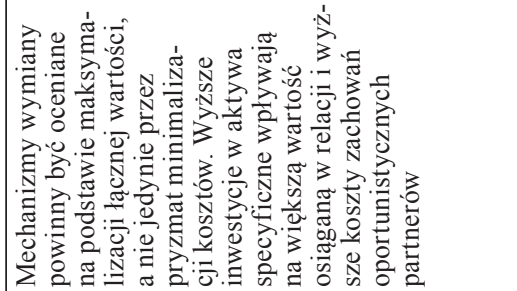 \\
\hline
\end{tabular}




\begin{tabular}{|c|c|c|c|c|c|c|}
\hline & 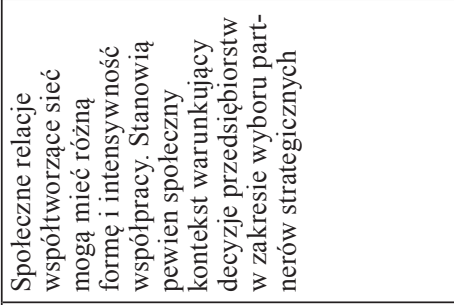 & & 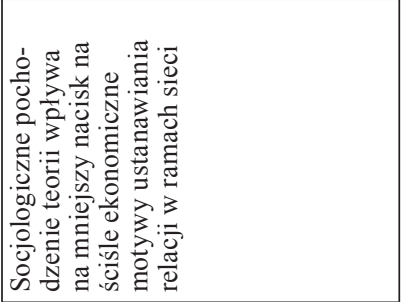 & & 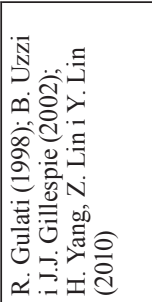 & 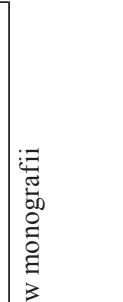 \\
\hline & 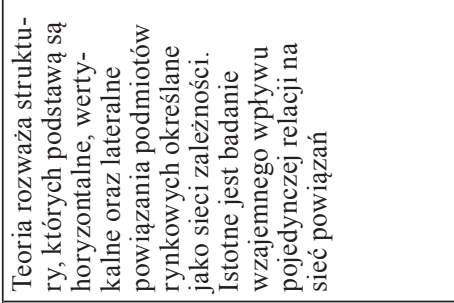 & & 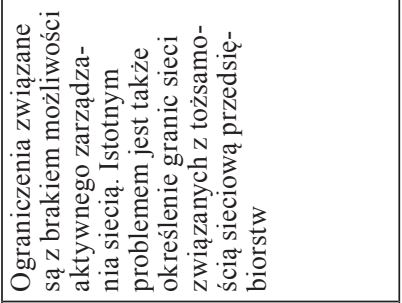 & & 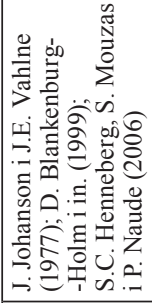 & 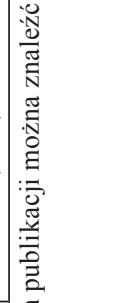 \\
\hline & 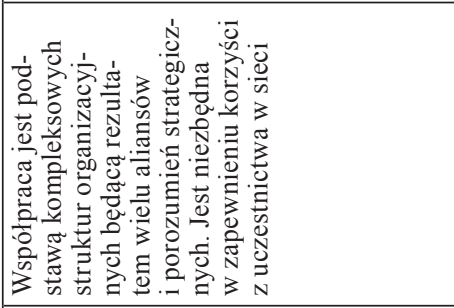 & 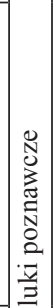 & 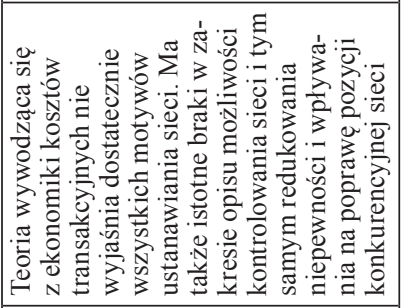 & 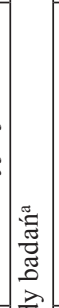 & 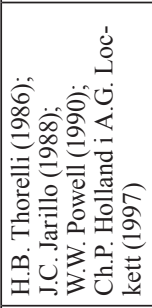 & 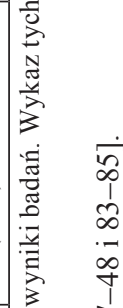 \\
\hline 5 & 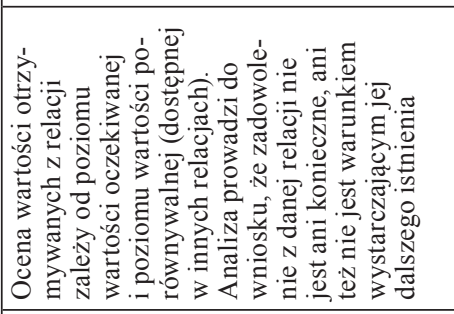 & 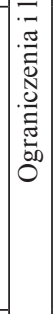 & 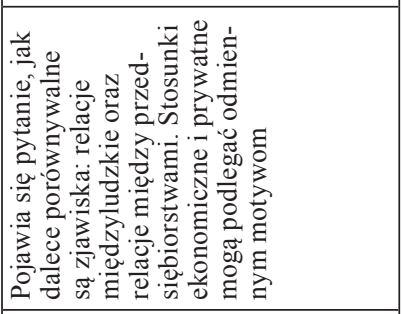 & 焉 & 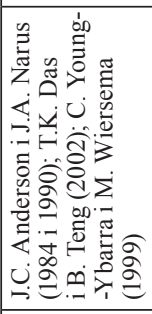 & 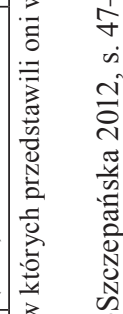 \\
\hline & 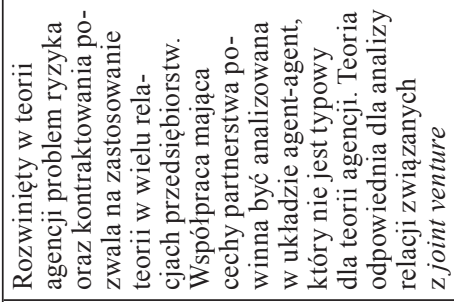 & & 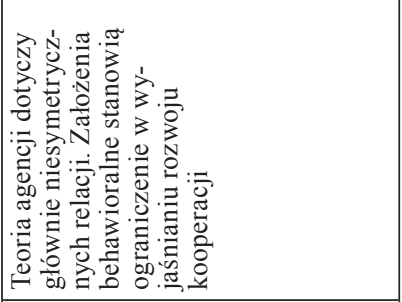 & & 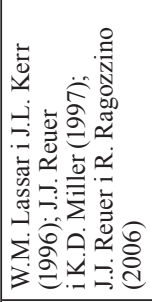 & 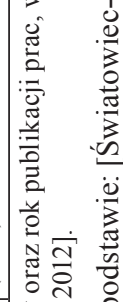 \\
\hline & 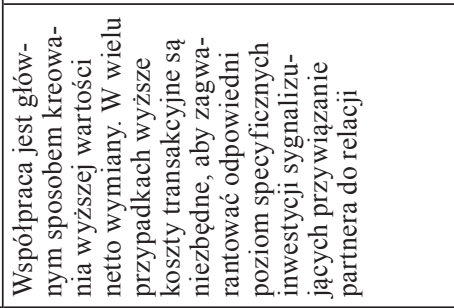 & & 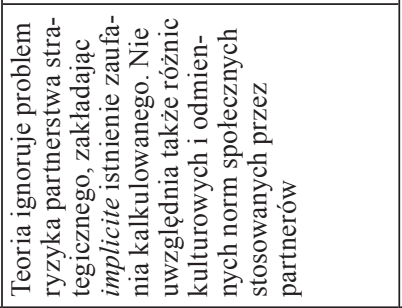 & & 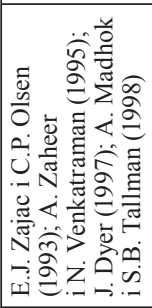 & 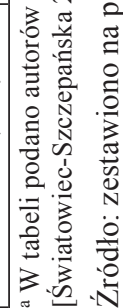 \\
\hline
\end{tabular}


zagadnienie współpracy, chociaż nie zostały uwzględnione w tabeli 1 . W ramach koncepcji gron nie jest ujmowana tylko współpraca przedsiębiorstw działających $\mathrm{w}$ tej samej branży i w tym samym regionie, ale także z szeroko pojętym otoczeniem. Natomiast paradygmat KKK omawia trzy siły regulujące mechanizm rynkowy, gdzie oprócz konkurencji i kontroli wymienia się współpracę jako równorzędny sposób działania międzyorganizacyjnego. Kapitalizm aliansowy ${ }^{3}$ to dotychczas ostatni z trzech wyodrębnionych etapów rozwoju kapitalizmu ${ }^{4}$. Wyraża się on w zmianie sposobu organizowania procesu produkcji i transakcji, lokalizacji zasobów i globalizacji, gdzie współpraca gospodarcza jest najistotniejszym czynnikiem rozwoju systemu ekonomicznego.

\section{Typologia współpracy przedsiębiorstw}

Z uwagi na wieloaspektowość współpracy gospodarczej oraz dużą liczbę badań w tym zakresie nie sposób zastosować uniwersalnego kryterium jej podziału. Analiza literatury przedmiotu ${ }^{5}$ pozwala na wyodrębnienie podziałów jedno- i wielokryterialnych [Światowiec-Szczepańska 2012, s. 33]. Istniejące typologie obejmują nierzadko odrębne płaszczyzny analiz, co sprzyja różnicowaniu wielu kryteriów podziału form współpracy przedsiębiorstw i wzajemnych relacji.

Zasadniczo każde przedsiębiorstwo ma do wyboru dwie ścieżki rozwoju (tabela 2): ścieżkę koncentracji lub ścieżkę kooperacji.

Poprzez kooperacje przedsiębiorstwa zawierają alianse strategiczne lub taktyczne, które są efektem pogłębiania się integracji, wzrostu konkurencji na rynku wspólnotowym oraz globalizacji gospodarki światowej ${ }^{6}$, niezmiernie szyb-

${ }^{3}$ Kategoria kapitalizmu aliansowego została wprowadzona do literatury przez M.L. Gerlacha. J.H. Dunning zbudował wokół tej kategorii koncepcję [Zorska 1998, s. 73].

4 Trzy etapy rozwoju kapitalizmu stanowią: 1) kapitalizm przedsiębiorczy (1770-1875) czas fabryk i dominacji małych firm); 2) kapitalizm hierarchiczny (od 1875 r. do początku lat 80. XX w.) - wielkie zintegrowane hierarchie korporacyjne; 3 ) kapitalizm aliansowy (według J.H. Dunninga, od 1985 r. do obecnych czasów) [Strzyżewska 2011, s. 49-50].

5 Jednym z najczęściej stosowanych podejść w rozróżnianiu typów relacji przedsiębiorstw jest kontinuum systemów wymiany, w którym rolę skrajnych form odgrywają transakcje oparte na rynku (kontrola rynku) oraz pełna integracja podmiotów dokonujących transakcji (kontrola biurokratyczna). Głównym kryterium, według którego przyporządkowane są poszczególne formy wymiany, jest stopień integracji organizacyjnej (struktura władztwa). Wybór struktury powinien być uzależniony od relacji korzyści i kosztów wymiany w danej formie [Światowiec-Szczepańska 2012, s. 34].

${ }^{6}$ Zdaniem D. Faulknera, a także K. Bleichera i R. Hermanna sukces każdego aliansu, a zwłaszcza międzynarodowego zależy od równoczesnego występowania dwóch czynników: 
Tabela 2. Strukturalizacja strategii rozwoju przedsiębiorstw

\begin{tabular}{|c|c|c|c|c|}
\hline \multirow{2}{*}{$\begin{array}{c}\text { Rozwój } \\
\text { wewnętrzny }\end{array}$} & \multicolumn{4}{|c|}{ Opcje strategiczne rozwoju przedsiębiorstw } \\
\cline { 2 - 5 } & \multicolumn{3}{|c|}{ Koncentracja } & \multicolumn{2}{c|}{ Kooperacja zewnętrzny } \\
\cline { 2 - 5 } & Fuzje & Przejęcia & $\begin{array}{c}\text { Alianse } \\
\text { strategiczne }\end{array}$ & Alianse taktyczne \\
\hline
\end{tabular}

Źródło: [Oczkowska 2006, s. 128].

kiego postępu technologicznego. Podkreśla się także konieczność współpracy przedsiębiorstw konkurujących ze sobą ${ }^{7}$. Alianse strategiczne to obecnie jeden ze sposobów przedsiębiorstwa nieposiadającego wystarczających zasobów lub cech konkurencyjności na osiągnięcie przewagi na rynku poprzez połączenie realizacji celów i zasobów z innym przedsiębiorstwem [Kuczewska 2002, s. 119; Barczak 2009]. Przyczyny zawierania aliansów strategicznych mają charakter zewnętrzny i wewnętrzny (tabela 3$)^{8}$.

Nie wszystkie porozumienia są uznawane za alianse strategiczne. Cechą charakterystyczną aliansów strategicznych jest realizacja określonego celu, ale przy założeniu niezależności partnerów. Do aliansów nie zalicza się wszelkiego typu kontraktów tradycyjnych, w tym kontraktów o kupnie/sprzedaży przy zachowaniu dystansu stron, franchisingu, licencji czy licencji wzajemnych,

dostosowania strategicznego i dostosowania kulturowego partnerów. Wiele badań potwierdza także zjawisko szkodliwej asymetryczności aliansów, które jest szczególnie widoczne w przypadku współpracy dużych przedsiębiorstw z krajów rozwiniętych z lokalnymi przedsiębiorstwami z krajów azjatyckich, południowoazjatyckich czy wschodnioeuropejskich [Zembura 2002, s. $140-141]$.

7 To rodzaj współpracy gospodarczej charakterystyczny dla ostatnich dwóch dekad. To współpraca między konkurentami aktualnymi i potencjalnymi. Relacje między konkurentami mogą być trwałe lub rozwijać się w różnych odstępach czasu w zależności od warunków zawartych w umowach. Chodzi tu o relacje podmiotów odrębnych ekonomicznie, niepodlegającym jakiemukolwiek centralnemu kierowaniu, a więc o relacji będącej domeną regulacji rynkowej a nie hierarchicznej, czyli wewnątrzorganizacyjnej [Cygler 2009, s. 15-19]. Współpraca i konkurencja umieszczone na jednym continuum znajdują się na skrajnych pozycjach. Jak podkreśla T.H. Chien i T.J. Peng, relacje firm mogą mieć charakter kooperacyjny lub konkurencyjny, lub mogą występować równocześnie [Chien i Peng 2005, s. 150]. Zjawisko to określa się w literaturze anglojęzycznej jako coopetition (od słów cooperation i competition) [Brandenburger i Nalebuff 1997], a w literaturze polskiej - kooperencja lub koopetycja [Noga 2009, s. 249]. Ze względu na planowanie kooperencja jest strategią rozwoju firm [Luo 2004, s. 32-33]. Co ciekawe, te same firmy w jednych obszarach mogą ze sobą konkurować, a w innych współpracować i konkurować [Strzyżewska 2011].

${ }^{8}$ Istnieje duża różnorodność w definiowaniu pojęcia aliansu. Szerokie rozumienie aliansów wskazuje, że sojusze mogą być zawierane przez przedsiębiorstwa tak z dostawcami i odbiorcami, jak też z obecnymi lub potencjalnymi konkurentami, a zatem mogą mieć charakter zarówno wertykalny, jak i horyzontalny [Gorynia 2007, s. 109-110; Oczkowska 2007, s. 104-105]. 
Tabela 3. Przyczyny zawierania aliansów strategicznych

\begin{tabular}{|l|l|}
\hline \multicolumn{1}{|c|}{ Przyczyny zewnętrzne } & \multicolumn{1}{c|}{ Przyczyny wewnętrzne } \\
\hline Globalizacja rynków i gustów & Nieadekwatność cech konkurencyjności \\
\hline Globalizacja technologii & Ograniczenie ryzyka w krótkim czasie \\
\hline $\begin{array}{l}\text { Korzyści skali, zasięgu i krzywa doświad- } \\
\text { czenia }\end{array}$ & $\begin{array}{l}\text { Tańsze aliansu niż porozumienia zintegro- } \\
\text { wanego }\end{array}$ \\
\hline Niepokoje gospodarcze & $\begin{array}{l}\text { Zabezpieczenie przed nieprzyjaznym } \\
\text { przejęciem }\end{array}$ \\
\hline
\end{tabular}

Źródło: [Kuczewska 2002, s. 119].

ponieważ nie prowadzą one do kontynuowania żadnego wspólnego przedsięwzięcia partnerów, w założeniu ograniczając się jedynie do kontaktów jednorazowych. Podobnie aliansów nie stanowią fuzje, przejęcia ani żadne inne operacje na własności, które prowadzą do utworzenia nowego, niezależnego podmiotu.

Aliansami mogą być wszelkie kontakty nietradycyjne, np. wspólne B+R, wspólny rozwój produktu czy wspólny marketing, które nie prowadzą do utraty niezależności przedsiębiorstw, ale dążą do realizacji wspólnie wyznaczonego celu strategicznego. Podobnie sojuszami strategicznymi mogą być wszelkie organizacje na własność, gdy nie powstaje nowa jednostka albo gdy powstanie jednostki wiąże się z likwidacją bądź utratą niezależności partnerów, jak np. niezależne joint venture [Cygler 2002, Romanowska 1997].

Na uwagę zasługuje szczególny rodzaj aliansu zwany multilateralnym lub wielostronnym. Tworzenie i zarządzanie tego typu aliansami w opinii J. Cygler należy do procesów niezwykle złożonych. Biorąc pod uwagę korzyści generowane przez powiązania sieciowe, wymienia ona sześć podstawowych grup przyczyn, które wpływają na tworzenie aliansów wielostronnych, a mianowicie: redukcje niepewności, zwiększenie elastyczności, możliwość pozyskania nowych zdolności rozwojowych, możliwość ułatwionego dostępu do deficytowych zasobów i umiejętności, nabywanie szybkości działania oraz pozyskiwanie informacji. J. Cygler wskazuje na ożywioną dyskusję praktyków i teoretyków zarządzania, której przedmiotem są kwestie tworzenia mnogich aliansów i ich konstelacji. Jedno z uwzględnianych podejść zakłada, że alianse wielostronne mogą tworzyć zróżnicowane struktury w zależności od liczby zawieranych sojuszy oraz liczby zaangażowanych w nich partnerów. Na podstawie tego kryterium J. Cygler wyróżnia jednorodne sieci aliansów, portfel aliansów oraz niejednorodne sieci aliansów. Przyjmując rozpowszechniony pogląd, że powiązania sieciowe są efektem procesu outsourcingu przedsiębiorstw, wyodrębnić można sieć wewnętrzną, sieć stabilną i sieć dynamiczną, natomiast według kryterium relacji pomiędzy uczestnikami układu, rozróżnia się sieci zdominowane od sieci 
równorzędnych partnerów. Sieci zdominowane obejmują alianse strategiczne, zawierane przez przedsiębiorstwo dominujące z kooperantami przejmującymi poszczególne funkcje łańcucha wartości korporacji. Sieci równorzędnych partnerów dotyczą podmiotów mających relatywnie podobne siły przetargowe w układzie. Specyficzną formą powiązań sieciowych są tzw. grona (klastry) [Cygler 2002, s. 161-193].

Sieci stanowią charakterystyczną, policentryczną formę organizacyjną tej działalności, która opiera się na współpracy i podziale pracy między przedsiębiorstwami. Sieć (zob. m.in. [Piontek 2006, Bembenek 2006, Staszewska 2007]) może przyjąć wiele różnych form: od luźnych porozumień o współpracy, umów dżentelmeńskich, poprzez umowy OEM (original equipment manufacturing), podzlecenie (subcontracting), franszyzę (franchising), joint venture, wzajemną wymianę lub wykup udziałów (cross sparing) do wirtualnego przedsiębiorstwa. Porozumienia mogą mieć charakter krótkotrwały i wiązać się przykładowo z jednym przedsięwzięciem lub mieć charakter długofalowy i przybierać postać partnerstwa czy aliansu strategicznego [Dworzecki i Żłobińska 2002, s. 300-304]. Przegląd typów sieci sporządzony przez J. Sydowa przedstawia tabela 4.

Tabela 4. Typologia sieci przedsiębiorstw

\begin{tabular}{|l|l|}
\hline \multicolumn{1}{|c|}{ Typ sieci } & \multicolumn{1}{c|}{ Wyjaśnienie, stosowane synonimy } \\
\hline $\begin{array}{l}\text { Przemysłowe } \\
\text { Usługowe }\end{array}$ & Przynależność sektorowa większości sieci \\
\hline $\begin{array}{l}\text { Sieci przedsiębiorstw } \\
\text { Sieci przedsiębiorstw nienastawionych na zysk }\end{array}$ & $\begin{array}{l}\text { Business networks } \\
\text { Non business networks }\end{array}$ \\
\hline $\begin{array}{l}\text { Strategiczne } \\
\text { Regionalne }\end{array}$ & $\begin{array}{l}\text { Główne ze względu na sposób kierowania } \\
\text { Strategic networks - small firms networks }\end{array}$ \\
\hline $\begin{array}{l}\text { Pionowe } \\
\text { Poziome }\end{array}$ & $\begin{array}{l}\text { Zależnie od położenia przedsiębiorstw w łań- } \\
\text { cuchu tworzenia wartości dodanej }\end{array}$ \\
\hline $\begin{array}{l}\text { Legalne } \\
\text { Nielegalne }\end{array}$ & $\begin{array}{l}\text { Zależnie od obowiązujących przepisów } \\
\text { (np. nielegalne kartele) }\end{array}$ \\
\hline $\begin{array}{l}\text { Dobrowolne } \\
\text { Przepisane }\end{array}$ & $\begin{array}{l}\text { Prawnie nakazana współpraca przedsiębiorstw } \\
\text { w jakiejś branży }\end{array}$ \\
\hline $\begin{array}{l}\text { Stabilne } \\
\text { Dynamiczne }\end{array}$ & $\begin{array}{l}\text { Stabilność członkostwa, ewentualnie stabil- } \\
\text { ność stosunków między przedsiębiorstwami }\end{array}$ \\
\hline $\begin{array}{l}\text { Wewnętrznie kierowane } \\
\text { Zewnętrznie kierowane }\end{array}$ & $\begin{array}{l}\text { Forma kierowania ze względu na miejsce } \\
\text { (np. przez osoby trzecie, organizację zarządza- } \\
\text { jącą siecią) }\end{array}$ \\
\hline $\begin{array}{l}\text { Scentralizowane } \\
\text { Zdecentralizowane }\end{array}$ & Stopień policentryczności \\
\hline $\begin{array}{l}\text { Formalne } \\
\text { Nieformalne }\end{array}$ & $\begin{array}{l}\text { Formalność, ewentualnie „,widoczność” takiej } \\
\text { sieci na rynku }\end{array}$ \\
\hline
\end{tabular}


cd. tabeli 4

\begin{tabular}{|c|c|}
\hline Typ sieci & Wyjaśnienie, stosowane synonimy \\
\hline $\begin{array}{l}\text { Otwarte } \\
\text { Zamknięte }\end{array}$ & Możliwość wejścia, wyjścia \\
\hline $\begin{array}{l}\text { Kierowane przez przedsiębiorstwo - producenta } \\
\text { Kierowane przez przedsiębiorstwo - nabywcę }\end{array}$ & Miejsce strategicznego kierownictwa \\
\hline $\begin{array}{l}\text { Zaopatrzeniowe } \\
\text { Produkcyjne } \\
\text { Informacyjne } \\
\text { Badawczo-rozwojowe } \\
\text { Marketingowe } \\
\text { Recyclingowe }\end{array}$ & $\begin{array}{l}\text { Zależnie od działalności przedsiębiorstwa, } \\
\text { która jest przez sieci realizowana na zasadach } \\
\text { kooperacji }\end{array}$ \\
\hline
\end{tabular}

Źródło: [Sydow 1999, s. 24] za: [Dworzecki i Żłobińska 2002, s. 304-305].

Analizując tabelę 4, można wyodrębnić sześć obszarów współpracy przedsiębiorstw zgrupowanych $\mathrm{w}$ ramach sieci, takich jak: zaopatrzenie, produkcja, przepływy informacyjne, działania badawczo-rozwojowe, marketing i recykling.

Odmienną formą od powiązań kooperacyjnych są koncentracyjne formy współpracy przedsiębiorstw, w których dochodzi do przejęcia słabszych przedsiębiorstw. Prowadzą one do utraty samodzielności ekonomicznej i prawnej, nazwy przejętej firmy, jej znaku firmowego itp. W koncentracyjnych formach współdziałania występują zależności i podporządkowania przedsiębiorstw o zróżnicowanym stopniu. Najważniejsze cechy wyróżniające kooperację od innych typów współpracy, a w szczególności od koncentracji, to: udział przynajmniej dwóch partnerów kooperacyjnych (w praktyce liczba kooperantów zależy od celu kooperacji i zadań szczegółowych), zachowanie własnej ekonomicznej samodzielności, wspólna realizacja zadań cząstkowych, dobrowolność współpracy rozumiana jako swoboda w zawieraniu i wypowiadaniu współpracy, umowny charakter współpracy partnerów kooperacyjnych, których rezultatem jest określenie celu wspólnego działania.

\section{Międzynarodowa współpraca przedsiębiorstw}

Ze względu na umiędzynarodowienie podstawowych elementów łańcucha wartości przedsiębiorstw (zob. [Filipowicz 2009, Światowiec 2006]), na który składają się: badania, rozwój, operacje, produkcja, logistyka i marketing, można wyróżnić trzy obszary współpracy międzynarodowej firm ${ }^{9}$.

9 Powiązania kooperacyjne z partnerami zagranicznymi to względnie długotrwałe związki gospodarcze, które mogą przyjąć postać kooperacji niekapitałowej, kooperacji kapitałowej oraz aliansów strategicznych [Gorynia 2007, s. 110]. 
Pierwszy obszar dotyczy umiędzynarodowienia badań naukowych i rozwoju nowych produktów. Polega na prowadzeniu powiązanych ze sobą prac badawczych i rozwojowych w różnych krajach, m.in. we współpracy z innymi przedsiębiorstwami w celu uzyskania nowych lub ulepszonych produktów oraz przełomowych wyników prowadzonych badań, których nie można byłoby osiągnąć bez międzynarodowej współpracy oraz obniżenia kosztów [Koźmiński 1999, s. 139-183].

Drugi obszar współpracy obejmuje operacje, produkcję, logistykę. Umożliwia on w zakresie logistyki sterowanie w skali międzynarodowej przepływami materialnymi, czyli strumieniami pochodzącymi z zewnątrz od dostawców i kooperantów, przepływami pomiędzy wewnętrznymi jednostkami firmy surowców, materiałów, komponentów i półproduktów oraz skierowanymi do odbiorców gotowych produktów, dóbr i usług [Koźmiński 1999, s. 139-183].

Trzeci obszar obejmuje umiędzynarodowienie marketingu, który oznacza przekroczenie pojęcia rynku dla działających na nim podmiotów. Podstawowym dylematem, który muszą rozstrzygnąć przedsiębiorstwa, jest wybór między standaryzacją i unifikacją elementów marketing miksu (produkt, cena, promocja i reklama oraz kanały dystrybucji), stosowanych w różnych krajach, a ich dostosowaniem do specyfiki tych krajów [Koźmiński 1999, s. 139-183].

Jedną z form międzynarodowej współpracy są powiązania gospodarcze między filiami zagranicznych korporacji a lokalnymi przedsiębiorstwami kraju goszczącego, które mogą przyjmować trzy kierunki: do tyłu (backword linkage), do przodu (forward linkages) i w poziome (horizontal) [World Investment Report, 2001]. Tabela 5 wyjaśnia charakter tych powiązań.

Zdaniem M. Goryni, lokalne przedsiębiorstwa nawiązujące współpracę z filiami KTN, określają kierunki rozwoju całego przedsięwzięcia, przez co są postrzegane jako ich inicjatorzy i liderzy zgodnie ze strategią lokalnego kooperanta. Od partnera zagranicznego oczekują transferu czynników, w których odnosi on przewagę nad partnerem lokalnym lub które są w ogóle niedostępne. Czynnikiem istotnie regulującym funkcjonowanie kontraktu jest zaniechanie ze strony partnera zagranicznego działań zmierzających do sprawowania efektywnej kontroli nad całością i ograniczenie jego zaangażowania do roli dostawcy swoich specyficznych przewag za uzgodnioną opłatę.

Jak podkreśla M. Gorynia [2007], niektóre z firm lokalnych stosujące strategie współpracy z międzynarodową firmą stają się gotowe do świadomego i uzasadnianego względami ekonomicznymi odseparowania się od inwestora zagranicznego. Najczęściej zarzucają zagranicznemu partnerowi niewywiązywanie się ze zobowiązań, brak dbałości o rozwój firmy (kazus firmy Emerson Polska, której niemiecki kooperant przechwytywał dywidendę, nie podejmując inwestycji podnoszących wartość firmy) oraz nadużywanie swojej pozycji i zmuszanie firmy 
Tabela 5. Współpraca gospodarcza między zagranicznymi a lokalnymi przedsiębiorstwami

\begin{tabular}{|c|c|c|c|}
\hline \multirow[b]{2}{*}{ Formy } & \multicolumn{3}{|c|}{ Relacje filii zagranicznych z lokalnymi przedsiębiorstwami } \\
\hline & $\begin{array}{c}\text { „do tyłu” } \\
\text { (zaopatrzenie) }\end{array}$ & $\begin{array}{l}\text { „do przodu" } \\
\text { (dystrybucja) }\end{array}$ & $\begin{array}{c}\text { pozioma kooperacja } \\
\text { w produkcji }\end{array}$ \\
\hline $\begin{array}{l}\text { Czyste transakcje } \\
\text { rynkowe }\end{array}$ & zakupy „,z półki” & sprzedaż „Z półki” & - \\
\hline $\begin{array}{l}\text { Powiązania } \\
\text { krótkoterminowe }\end{array}$ & $\begin{array}{l}\text { ciągłe lub sporadyczne } \\
\text { zakupy na zamówie- } \\
\text { nie }\end{array}$ & $\begin{array}{l}\text { ciągła lub spora- } \\
\text { dyczna sprzedaż } \\
\text { na zamówienie }\end{array}$ & - \\
\hline $\begin{array}{l}\text { Powiązania } \\
\text { długoterminowe }\end{array}$ & $\begin{array}{l}\text { - długoterminowe } \\
\text { kontrakty na } \\
\text { dostawę produktów } \\
\text { do dalszej produkcji } \\
\text { - podwykonawstwo } \\
\text { w zakresie dostawy } \\
\text { półproduktu lub } \\
\text { produktu finalnego }\end{array}$ & $\begin{array}{l}\text { - długoterminowe } \\
\text { kontrakty z lokal- } \\
\text { nymi dystrybuto- } \\
\text { rami lub ostatecz- } \\
\text { nymi odbiorcami } \\
\text { - outsourcing lokal- } \\
\text { nych firm w zagra- } \\
\text { nicznych filiach }\end{array}$ & $\begin{array}{l}\text { wspólne projekty filii } \\
\text { zagranicznej z lokalną } \\
\text { konkurencyjną firmą }\end{array}$ \\
\hline Relacje własnościowe & $\begin{array}{l}\text { - utworzenie joint } \\
\text { venture z dostaw- } \\
\text { cami } \\
\text { - utworzenie nowej } \\
\text { filii zaopatrzeniowej } \\
\text { przez zagraniczną } \\
\text { korporację }\end{array}$ & $\begin{array}{l}\text { - utworzenie joint } \\
\text { venture z lokalnymi } \\
\text { dystrybutorami } \\
\text { lub (i) z ostatecz- } \\
\text { nymi odbiorcami } \\
\text { - utworzenie nowej } \\
\text { filii dystrybucyjnej } \\
\text { przez zagraniczną } \\
\text { korporację }\end{array}$ & $\begin{array}{l}\text { - joint venture } \\
\text { w zakresie koopera- } \\
\text { cji poziomej } \\
\text { - utworzenie przez } \\
\text { zagraniczną kor- } \\
\text { poracje nowej filii } \\
\text { produkującej te } \\
\text { same produkty }\end{array}$ \\
\hline
\end{tabular}

Źródło: [World Investment Report 2001, s. 158].

lokalnej do zawierania niekorzystnych dla niej transakcji (przykład krakowskiej firmy Vistula, której holenderscy kooperanci sprzedawali po zawyżonych cenach surowce i ubrania o niskiej jakości, a także mało przydatne materiały reklamowe i usługi konsultingowe). Przedsiębiorstwa lokalne, w opinii M. Goryni, wiedzą, że partner zagraniczny prowadzi politykę zabezpieczającą głównie własne interesy, co w sposób naturalny czyni przyszłość firmy lokalnej niepewną, jak np. spółki Partner Serwis oraz Partner Elektra. Wspomniane firmy dokonały zwrotu od strategii kooperacji do strategii walki nakierowanej na identyfikację własnego miejsca na rynku już po rozstaniu się z zagranicznym kooperantem [Gorynia 2007, s. 150-153]. 


\section{Korzyści i zagrożenia współpracy przedsiębiorstw}

Celem współpracy jest osiągnięcie dodatkowych korzyści przez każde z uczestniczących przedsiębiorstw. Korzyści muszą być wyższe niż wynikające $z$ rezultatów działań we własnym zakresie. Określa się je jako renta współpracy ${ }^{10}$, a jej osiągnięcie jest skutkiem efektu synergii. Źródłem wartości dodanej jest nowa jakość zasobów (gdy współpracujące firmy posiadały komplementarne zasoby, które wzajemnie uzupełniły) i (lub) nowa wielkość zasobów (gdy współpracujące przedsiębiorstwa w celu realizacji określonych projektów uzupełniały niewystarczające wielkości podobnych zasobów).

Przedsiębiorstwa mogą odczuwać ujemne efekty współpracy, prowadzące nieuchronnie do osłabienia relacji. Zjawisko to jest nazywane efektem dyssynergii. Nawet w sytuacji osiągania wysokiej renty współpracy niesprawiedliwy rozkład korzyści będzie skutkował rozpadem grupy [Strzyżewska 2011, s. 30-32].

N.A. Peña i J.C. Fernández de Arroyabe [2002, s. 39] wyodrębnili zalety i wady współpracy przedsiębiorstw. Do zalet zaliczyli:

- zwiększenie zdolności i kompetencji bez konieczności nabywania i rozwijania nowych zasobów i umiejętności,

- oszczędność czasu w stosunku do konkurentów,

- elastyczność przedsiębiorstwa w dostosowywaniu się do nowych warunków działania.

Wady współpracy to:

- ograniczenie pełnej autonomii/swobody działania przedsiębiorstwa przez konieczność kontrolowania jego funkcjonowania w obszarze objętym przedmiotem współpracy w zamian za poszukiwane zasoby, co jest częstym powodem niechęci do podjęcia współpracy,

- konieczność harmonizacji i koordynacji decyzji i działań dwóch lub więcej niezależnych organizacji, często o różnych strukturach organizacyjnych i kulturze, co może prowadzić do konfliktów i utrudniać współpracę, a także skutkować obniżeniem dotychczasowej wydajności przedsiębiorstwa,

- utrata/rozproszenie dotychczasowych, strategicznych zasobów/umiejętności przedsiębiorstwa poprzez naukę technologii przez firmy współpracujące, które mogą dokonywać jej modyfikacji lub na jej podstawie budować swoje strategiczne zasoby/umiejętności.

10 „Wydaje się, że opisowość i nieprecyzyjność tego pojęcia pozwalają powrócić do marshalowskiego sformułowania (1890 r.) quasi-renty. Jest to nadwyżka produktywności przy zastosowaniu komplementarnych zasobów (renta różniczkowa). Ponieważ źródłem jej jawi się kooperacja, zasadne jest określenie quasi-renty - organizacyjnej” [Sulejewicz 1997, s. 116]. 


\section{Wnioski}

Problematyka współpracy gospodarczej jest zagadnieniem wielopłaszczyznowym, dlatego w niniejszym opracowaniu dokonano selektywnego wyboru jej poszczególnych aspektów uznanych za najważniejsze. Omówiono istotę współpracy gospodarczej, scharakteryzowano jej typy oraz podjęto próbę przedstawienia znaczenia współpracy gospodarczej dla uczestniczących w niej podmiotów, przez co pozytywnie zweryfikowano hipotezę badawczą: współpraca gospodarcza stanowi jedno z głównych uwarunkowań rozwoju współczesnego przedsiębiorstwa. Należy stwierdzić, że efekt współpracy może być postrzegany jako korzystny dla wszystkich lub korzystny dla części jej uczestników, a neutralny lub niekorzystny dla pozostałej części współpracujących podmiotów, jak również neutralny bądź niekorzystny dla wszystkich podmiotów [Peña i Fernández de Arroyabe 2002, s. 37-39]. Podejmując współpracę gospodarczą, powinno się zakładać nie tylko osiągnięcie wymiernych korzyści, ale także być pewnym ich wystąpienia i utrzymania. Współpraca wymaga niejednokrotnie poniesienia dodatkowych kosztów, nierzadko większego zaangażowania jednej ze stron, co jest możliwe tylko w sytuacji pełnego zaufania uczestników. Konsekwencją braku zaufania jest wzrost kosztów transakcyjnych, generowanych przez wprowadzenie dodatkowych kosztów nadzoru i kontroli, oraz kosztów alternatywnych, definiowanych jako poświęcony czas, wysiłek włożony w negocjacje poprzedzające zawarcie umowy. Współpracę uważa się za korzystną pod względem finansowym, gdy jej koszty są niższe od kosztów prowadzenia działalności przez przedsiębiorstwo indywidualnie.

\section{Literatura}

Barczak B. [2009], Alianse wielostronne jako koncepcja zarzadzania rozwojem przedsiębiorstw [w:] Instrumenty i obszary przeobrażeń i zmian organizacyjnych $w$ warunkach globalizacji, red. A. Potocki, Difin, Warszawa.

Bembenek B. [2006], Partnerstwo w klastrze szansa wzmocnienia konkurencyjności przedsiębiorstwa [w:] Klastry jako narzędzia lokalnego i regionalnego rozwoju gospodarczego, red. E. Bajor, Wydawnictwo Politechniki Lubelskiej, Lublin.

Brandenburger A.M., Nalebuff B.J. [1997], Co-opetition: A Revolutionary Mindset That Combines Competition and Cooperation: The Game Theory Strategy That's Changing the Game of Business, Harper Collins Business, London.

Chien T.H., Peng T.J. [2005], Competition and Cooperation Intensity in a NetworkA Case Study in Taiwan Symulator Industry, „The Journal of American Academy of Business", vol. 7, $\mathrm{nr} 2$.

Cygler J. [2009], Kooperencja przedsiębiorstw. Czynniki sektorowe i korporacyjne, Oficyna Wydawnicza Szkoła Główna Handlowa w Warszawie, Warszawa.

Cygler J. [2002], Alianse strategiczne, Difin, Warszawa. 
Dunning J.H. [1995], Reappraising of the Eclectic Paradigm in the Age of Alliance Capitalism, „Journal of International Business Studies”, vol. 26, nr 3, https://doi.org/ 10.1057/palgrave.jibs.8490183.

Dunning J.H. [1997], Alliance Capitalism and Global Business, Rotledge, London.

Dworzecki Z., Żłobińska A. [2002], Regionalne sieci przedsiębiorstw jako globalna szansa dla małych i średnich przedsiębiorstw [w:] Przedsiębiorstwo kooperujace, red. Z. Dworzecki, Euro Expert Grupa Doradcza Sp. z o.o., Warszawa.

Famielec J. [1992], Układy kooperacyjne w gospodarce rynkowej-doświadczenia, strategie, Akademia Ekonomiczna w Krakowie, Kraków.

Filipowicz P. [2009], Innowacyjność przedsiębiorstwa a proces tworzenia wartości wybrane modele strategii [w:] Instrumenty i obszary przeobrażeń i zmian organizacyjnych $w$ warunkach globalizacji, red. A. Potocki, Difin, Warszawa.

Gorynia M. [2007], Strategie zagranicznej ekspansji przedsiębiorstw, PWE, Warszawa.

Instrumenty i obszary przeobrażeń i zmian organizacyjnych $w$ warunkach globalizacji [2009], red. A. Potocki, Difin, Warszawa.

Jagoda H. [2001], Formy współdziałania gospodarczego w procesie transformacji polskiej gospodarki [w:] Strategie i konkurencyjność przedsiębiorstw po dziesięciu latach transformacji, red. M. Moszkowicz, Politechnika Wrocławska PAN, Oddział we Wrocławiu, Wydawnictwo Wydziału Zarządzania Politechniki Częstochowskiej, Częstochowa.

Koźmiński A.K. [1999], Zarządzanie międzynarodowe. Konkurencja w klasie światowej, PWE, Warszawa.

Kuczewska J. [2002], Alianse strategiczne jako forma wspólpracy przedsiębiorstw europejskich [w:] Przedsiębiorstwo kooperujace, red. Z. Dworzecki, Euro Expert Grupa Doradcza Sp. z o.o., Warszawa.

Luo Y. [2004], Coopetition in International Business, CBS Press, Copenhagen.

Noga A. [2009], Teorie przedsiębiorstw, PWE, Warszawa.

Oczkowska R. [2006], Joint venture jako alians przedsiębiorstw na rynku międzynarodowym - rozważania terminologiczno-definicyjne, „Zeszyty Naukowe Akademii Ekonomicznej w Krakowie", nr 720.

Oczkowska R. [2007], Przedsiębiorstwo na rynku międzynarodowym, Krakowska Oficyna Wydawnicza AFM, Kraków.

Partnerstwo przedsiębiorstw jako czynnik ograniczania ryzyka działalności gospodarczej [2009], red. H. Brdulak, E. Duliniec, T. Gołębiowski, SGH, Warszawa.

Peña N.A., Fernández de Arroyabe J.C. [2002], Business Cooperation. From Theory to Practice, Palgrave Macmilian, New York.

Piontek B. [2006], Pomiar gospodarki sieciowej jako podstawa dla tworzenia klastrów w układach lokalnych [w:] E. Bajor, Klastry jako narzędzia lokalnego i regionalnego rozwoju gospodarczego, Wydawnictwo Politechniki Lubelskiej, Lublin.

Przedsiębiorstwo kooperujące [2002], red. Z. Dworzecki, Euro Expert Grupa Doradcza Sp. z o.o., Warszawa.

Przedsiębiorstwo partnerskie [2002], red. M. Romanowska, M. Trocki, Difin, Warszawa.

Romanowska M. [1997], Alianse strategiczne przedsiębiorstw, PWE, Warszawa.

Romanowska M., Trocki M. [2002], Przedsiębiorstwo partnerskie - w poszukiwaniu równowagi między rywalizacja i współdziałaniem, „MBA”, nr 6.

Staszewska J. [2007], Rozwój przedsiębiorstw sieciowych w Polsce-perspektywy dla klasteringu, „Przegląd Organizacji”, nr 11. 
Strzyżewska M. [2011], Wspótpraca między przedsiębiorstwami-odniesienie do polskiej praktyki, Oficyna Wydawnicza SGH, Warszawa.

Sulejewicz A. [1997], Partnerstwo strategiczne: modelowanie współpracy przedsiębiorstw, SGH, Warszawa.

Sydow J. [1999], Mitbestimmung und neue Unternehmungsnetzwerke, Berlin.

Światowiec J. [2006], Koncepcja wartości jako podstawa współpracy przedsiębiorstw, „Przegląd Organizacji”, nr 4.

Światowiec-Szczepańska J. [2012], Ryzyko partnerstwa strategicznego przedsiębiorstw. Ujęcie modelowe, Wydawnictwo Uniwersytetu Ekonomicznego w Poznaniu, Poznań.

Urbaniak M. [2000], Wspótpraca przedsiębiorstwa z dostawcami w ramach marketingu partnerskiego, „Gospodarka Materiałowa i Logistyka”, nr 5.

World Investment Report [2001], Promoting Linkages, UNCTAD, United Nations, New York-Geneva.

Zembura R. [2002], Wewnętrzne czynniki sukcesu aliansu [w:] Przedsiębiorstwo kooperujace, red. Z. Dworzecki, Euro Expert Grupa Doradcza Sp. z o.o., Warszawa.

Zorska A. [1998], Ku globalizacji? Przemiany w korporacjach transnarodowych $i$ w gospodarce światowej, PWN, Warszawa.

\section{Economic Cooperation as a Factor in the Development of Modern Enterprise} (Abstract)

Economic cooperation is a multifaceted concept that is difficult to classify. Numerous scientific studies have confirmed the complexity of organisational relationships and the forms they take. This short paper examines the benefits and risks of economic cooperation and, using a review of the literature, discusses the theoretical essence of economic cooperation, the forms it takes and the importance it carries for the entities cooperating. It is hypothesised that economic cooperation is one of the main conditions modern enterprises must engage if they wish to develop.

Keywords: economic cooperation, cooperation, concentration, company, transnational corporations. 